
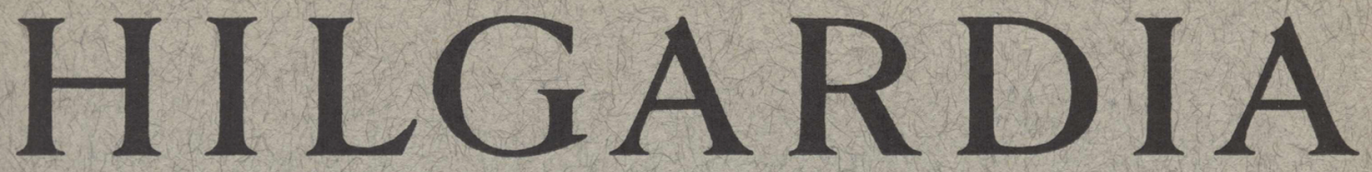

A Journal of Agricultural Science Publisbed by the California Agricultural Experiment Station

\title{
SYMPTOMS OF CUCUMBER-MOSAIC AND TOBACCO-RINGSPOT VIRUSES ON CELERY
}

\author{
HENRY H. P. SEVERIN
}




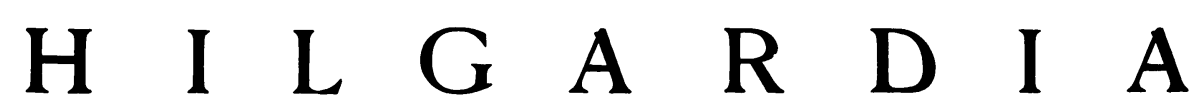

A Journal of Agricultural Science Published by

the California Agricultural Experiment Station

VoL. 20

OCTOBER, 1950

No. 14

\title{
SYMPTOMS OF CUCUMBER-MOSAIC AND TOBACCO- RINGSPOT VIRUSES ON CELERY ${ }^{1}$
}

\author{
HENRY H. P. SEVERIN ${ }^{2}$
}

\section{INTRODUCTION}

A REview of the literature discloses a number of cucumber-mosaic viruses infecting celery. Doolittle and Wellman $(1934)^{3}$ described the symptoms of southern celery mosaic in Florida. Wellman (1934) considers the virus causing the disease a new one. He reached this decision when a comparative study of southern celery-mosaic virus and common cucumber-mosaic virus disclosed a difference in certain physical properties and in symptoms produced on differential host plants. Wellman gives southern celery mosaic the designation "celery virus 1." He does state, however, that "It is believed upon careful study of symptoms described in reports of celery mosaics by Poole (1922), Elmer (1925), and Harvey (1925), that these investigators were working with common cucumber mosaic (Cucumber virus 1, Doolittle)."

Price (1935), after a comparison of southern celery-mosaic and common cucumber-mosaic viruses, came to the conclusion that the two viruses are closely related immunologically, and, it is believed, should be classified as strains of the same virus.

Smith (1937) reported southern celery-mosaic virus to be synonymous with common cucumber-mosaic virus. It would seem, therefore, that Smith (1937) would have been more accurate in classifying Wellman's (1934) southern celery-mosaic virus as a strain of common cucumber mosaic rather than as the same virus. Smith (1937) classified Doolittle's (1920) cucumbermosaic virus as "Cucumis virus 1 ," adding this name to the names already applied to the virus.

Holmes (1939) classified common cucumber-mosaic virus as cucumbermosaic virus, typical strain, Marmor cucumeris var. vulgare.

Field investigations were undertaken in the Salinas Valley by the author to determine whether this strain of common cucumber-mosaic virus had established itself on celery transplanted from Florida and grown in the valley. Studies were made of the sequence of symptoms of three cucumbermosaic viruses produced on Golden Self-blanching celery (Apium graveolens

\footnotetext{
${ }^{1}$ Received for publication October 17, 1949.

2 Entomologist in the Experiment Station.

"See "Literature cited" for data on citations, referred to in text by author and date.
} 
var. dulce). The purpose of these studies was to determine whether any symptom of common cucumber mosaic on celery could be distinguished from symptoms of western cucumber mosaic and celery calico. The symptoms of tobacco ringspot on the leaves of celery are described, but the virus is not known to infect this host plant in nature.

\section{CELERY CALICO}

Celery calico has been found in all of the large celery districts in California (Severin and Freitag, 1938). The disease occurs in the interior regions and in the coastal fog belt.

The symptoms and illustrations of calico on celery have been described in a previous paper (Severin and Freitag, 1938). Considerable variation occurs in the development of the early symptoms of celery calico. The symptom which sometimes develops first in the greenhouse is a clearing of the veins, with a slight yellowing along them, and a puckering and downward cupping of the younger leaves. Frequently no vein clearing occurs, but a faint yellowing develops near the basal region of the leaflets, or pale-yellow bands appear across the leaflets and later change to amber yellow or pale orange. Often the leaflets are orange in color with green margins (plate $1, A$ ), or sometimes the same symptoms appear on the leaflets on one side of the rachis and on the opposite side the leaflets are green (plate $1, B$ ). A reliable symptom in a later stage of the disease is green islands in the lemon-yellow areas (plate $1, C$ ) of the outer leaves. Sometimes the green areas are surrounded by chlorotic rings. In the more advanced stage of the disease, the leaflets may show green and yellow zigzag bands and many small green islands.

\section{WESTERN CUCUMBER MOSAIC}

Western cucumber mosaic occurs only in the interior regions of California and not in the coastal fog belt.

Cleared veins and veinlets are the first symptoms of western cucumber mosaic which sometimes appear on the youngest leaves of celery; this is followed by slightly elevated green areas surrounded by cleared veinlets. Often, however, no clearing of the veins and veinlets occurs. Instead, the intermediate leaves develop interveinal, chlorotic areas (plate 2, A), which later coalesce (plate $2, B$ ). Green islands in the yellow areas appear on some of the leaflets (plate $2, C$ ), resembling somewhat similar symptoms of celery calico. On the oldest leaves, yellow or orange discolorations occur along the margin of the leaflets (plate $2, D$ ), and later the oldest leaves become chlorotic (plate $2, E$ ).

In the late stage of western cucumber mosaic, necrosis along the veins may occur and spread throughout the interveinal spaces (plate $2, F$ ). Some of the oldest leaves develop green blister-like elevations (plate $3, A$ ), or the leaflets may be dwarfed with green islands in the yellow areas (plate $3, B$ ). Sometimes the leaflets on one side of the rachis are chlorotic and twisted and on the opposite side green and apparently normal (plate 3,C). Frequently the leaflets are dwarfed, twisted, and curled (plate $3, D$ ). Necrosis of the petioles occurs on naturally infected celery grown in the Tulare district but rarely on experimentally infected plants. 


\section{COMMON CUCUMBER MOSAIC}

Common cucumber mosaic is not known to have occurred in the field in California up to the present time. There was no evidence that southern celery mosaic has established itself in the Salinas Valley, although celery from Florida was transplanted in the field.

The first symptom of common cucumber mosaic on the youngest leaves of celery 10 days after inoculation is a conspicuous clearing of the veins and veinlets on the youngest leaves (plate $4, A$ ). A few days later, green areas slightly elevated are surrounded by the cleared veins (plate $4, B$ ). The youngest leaves become puckered, crinkled, and cupped downward with shortened petioles. The heart of the plant is stunted. Interveinal, small circular chlorotic areas appear on the intermediate leaves (plate $4, C$ ). On the older leaves, the chlorotic circular areas are more conspicuous; later they fuse and form yellow bands along the vein or along the zigzag bands across the leaflets (plate $4, D)$.; frequently the margin of the leaflets is yellow (plate $4, E)$. Green islands surrounded by yellow rings are embedded in chlorotic areas (plate $4, F)$. They appear on the intermediate and the oldest leaves and resemble this symptom of celery calico (plate $1, C$ ). The intermediate leaves gradually assume a yellow or orange color and finally become chlorotic (plate 5, A). The margins of the outer leaves become white.

In the advanced stage of the disease, necrosis of the veins occurs (plate 5 , $B, C)$. Rust-colored, necrotic spots appear on the leaves (plate $5, D$ ), and increase in number (plate $5, E$ ). This symptom is followed by necrosis of the leaflets. The severe necrosis of the petioles of the younger leaves (plate $5, F$ ), is followed by wilting and drying of the leaves.

\section{TOBACCO RINGSPOT}

The virus of tobacco ringspot has not been recovered from celery grown under natural conditions in California.

The first symptom of tobacco ringspot on celery 9 to 20 days after inoculation, is a clearing of the veins and veinlets (plate 6, $A$ ). This is followed by the appearance of interveinal circular green areas elevated on the upper surface of the leaflets (plate $6, B$ ). Numerous circular chlorotic areas appear on the youngest leaflets (plate $6, C$ ), each with a rust-colored necrotic center. While the youngest leaflets develop the symptoms described, various patterns appear on the intermediate leaves. On the intermediate leaves circular chlorotic areas also appear; these later coalesce (plate $6, D$ ). Later some of the intermediate leaves develop yellow or orange discolorations (plate $6, E$ ). Chlorosis gradually spreads over the intermediate leaflets (plate $6, F^{\prime}$ ). The outer or older leaves frequently become puckered, with numerous circular yellow spots and slightly elevated green areas. In a late stage of the disease, necrotic spots appear on the leaves.

\section{SUMMARY}

The symptoms of celery calico, western cucumber mosaic, common cucumber mosaic, and tobacco ringspot are described as they appear in sequence on Golden Self-blanching celery (Apium graveolens var. dulce). 
Celery calico has been found in all of the large celery districts in the state. Western cucumber mosaic occurs only in the interior regions of California. Common cucumber mosaic and tobacco ringspot are not known to occur on celery in any celery district in the state.

A reliable symptom of celery calico in its later stage under natural conditions is the appearance of green islands in the lemon-yellow areas on the intermediate and outer leaves. In the late stage of western celery mosaic, necrosis may occur along the veins and spread throughout the interveinal spaces. Necrosis of the petioles occurs on naturally infected celery.

On celery experimentally infected by the three cucumber-mosaic viruses, much overlapping of symptoms occurs. The symptoms of common cucumber mosaic can be distinguished from the symptoms of celery-calico and westerncucumber-mosaic viruses on the leaves of celery by the rust-colored necrotic areas on the leaflets in the advanced stage of the disease, but cannot be separated from similar symptoms produced by the tobacco-ringspot virus. Severe necrosis of the celery petioles occurs with common cucumber mosaic and not with celery calico. In the advanced stage of common cucumber mosaic on celery there is a severe stunting of the plant. The central young petioles are shortened, and the outer petioles are horizontal instead of upright, which gives the top of the plant a flattened appearance. No such symptoms occur with celery infected with celery calico and western cucumber mosaic.

\section{LITERATURE CITED}

Doolitwle, S. P.

1920. The mosaic disease of cucurbits. U. S. Dept. Agr. Bul. 879:1-69.

DoolitTle, S. P., and F. L. Werllman.

1934. Commelina nudiflora, a monocotyledonous host of celery mosaic in Florida. Phytopathology 24(1):48-61.

ELMER, O. H.

1925. Transmissibility and pathological effects of the mosaic diseases. Iowa Agr. Exp. Sta. Res. Bul. $82: 39-91$.

HARvex, R. B.

1925. Blanching celery. Minnesota Agr. Exp. Sta. Bul. 222 :1-20.

Holmes, Francis O.

1939. Handbook of phytopathogenic viruses. 221 p. Burgess Pub. Co., Minneapolis, Minnesota.

PoOLe, R. F.

1922. Celery mosaic. Phytopathology $12(3): 151-54$.

PrICE, W. C.

1935. Classification of southern celery-mosaic virus. Phytopathology 25(10):947-54.

Severin, H. H. P., and J. H. Freitag.

1938. Western celery mosaic. Hilgardia $11(9): 494-558$.

SмITH, K. M.

1937. A textbook of plant virus diseases. 615 p. P. Blakiston's Son \& Co., Inc. Philadelphia, Pennsylvania.

WELLMAN, F. L.

1934. Identification of celery virus 1 , the cause of southern celery mosaic. Phytopathology $24(7): 695-725$. 


\section{PLATES}




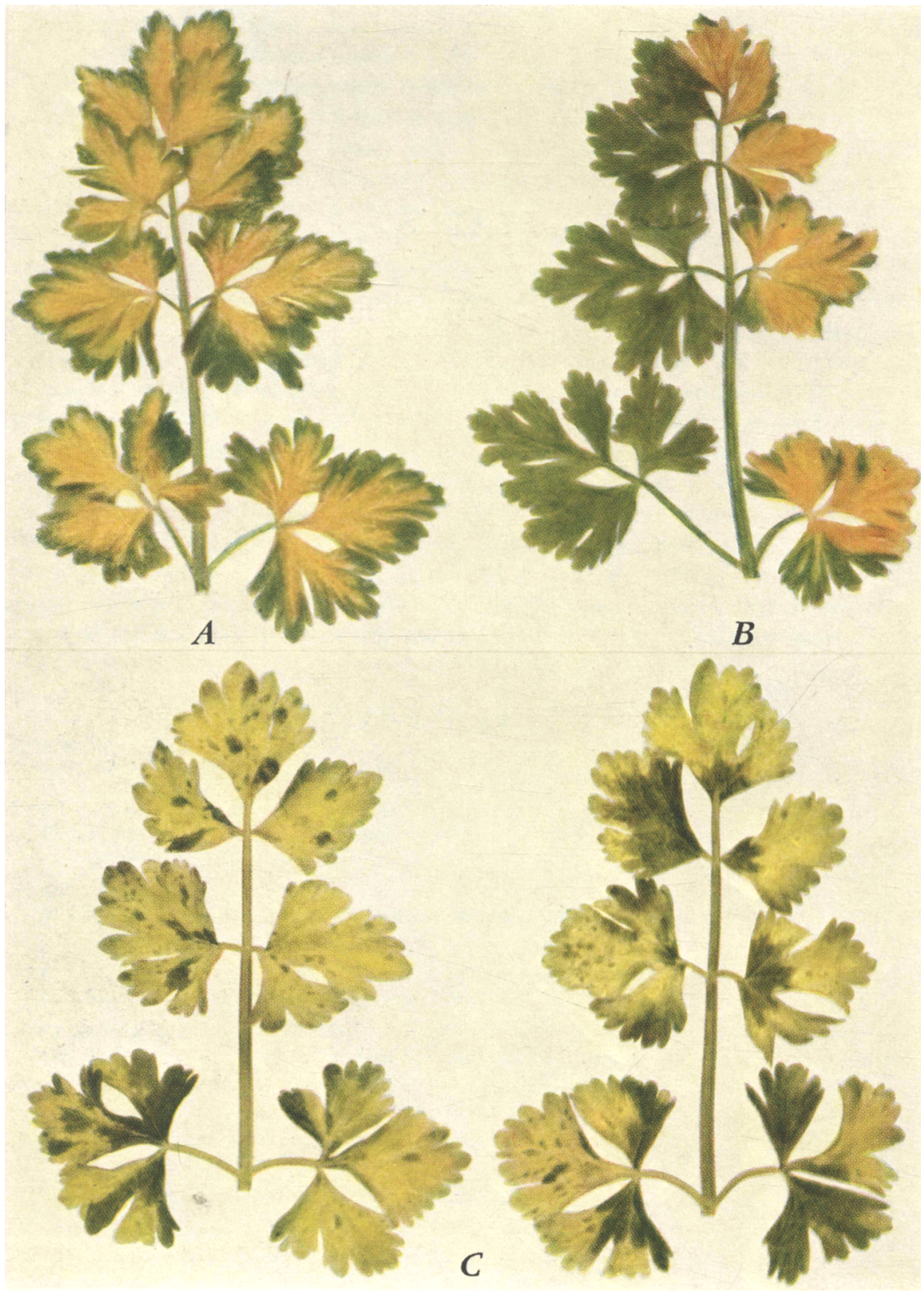

Plate 1. Symptoms of celery calico on leaflets of Golden Self-blanching celery (Apium graveolens var. dulce) : $A$, orange-colored leaflets with green margins; $B$, orange-colored leaflets with green margins on one side of the rachis and green leaflets on the opposite side; $C$, leaves showing green islands in lemon-yellow areas from plants infected with the virus by the cotton or melon aphid (Aphis gossypii). 


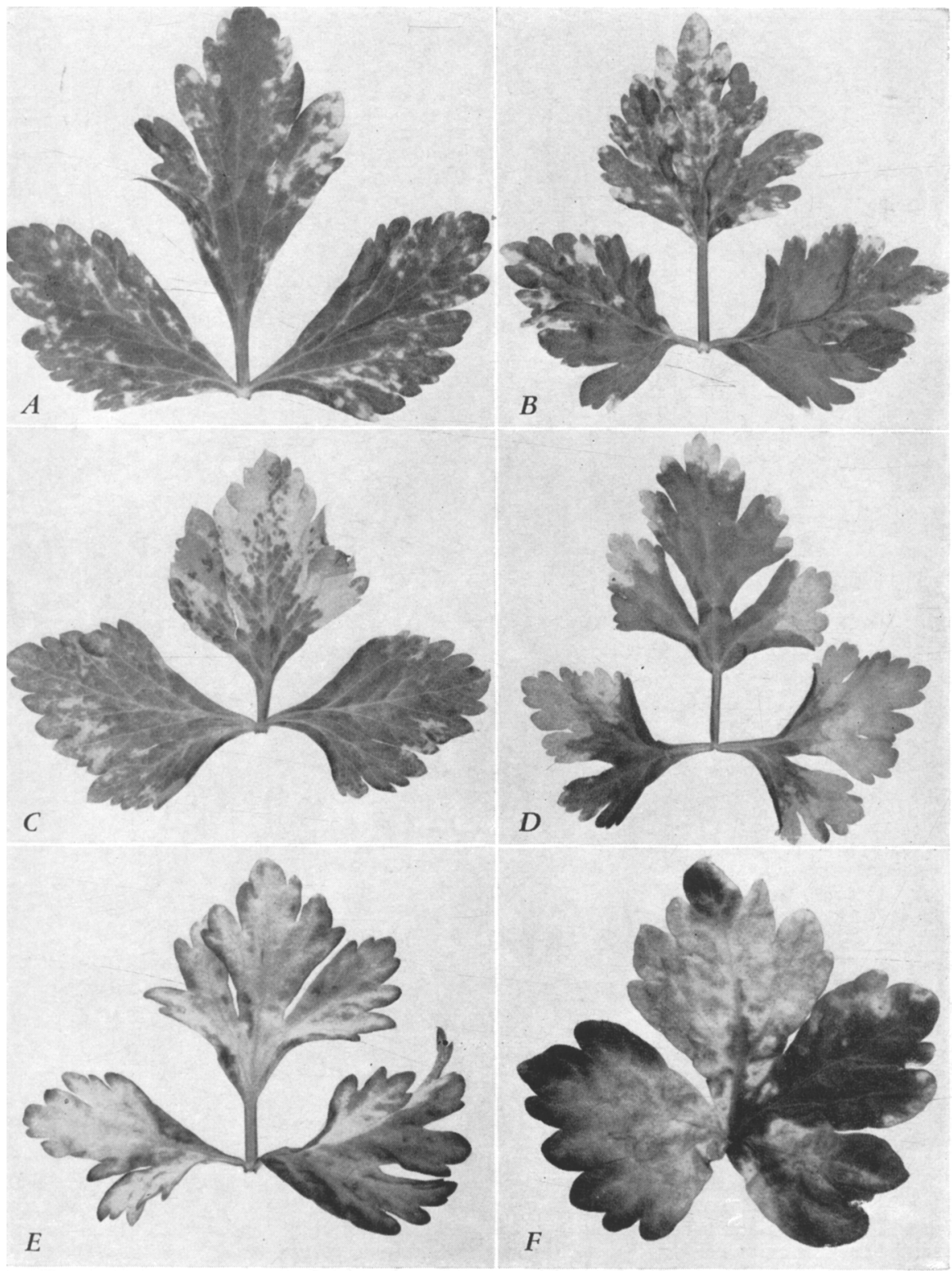

Plate 2. Symptoms of western cucumber mosaic on leaves of experimentally infected Golden Self-blanching celery (Apium graveolens var. dulce) : A, chlorotic areas between the veins ; $B$, fusion of chlorotic areas ; $C$, green islands in yellow areas, resembling similar symptoms of celery calico; $D$, yellow or orange discolorations along the margin of the leaflets ; $\boldsymbol{E}$, chlorosis of leaflets; $\boldsymbol{F}$, orange discoloration of leaflets and necrosis of veins. 

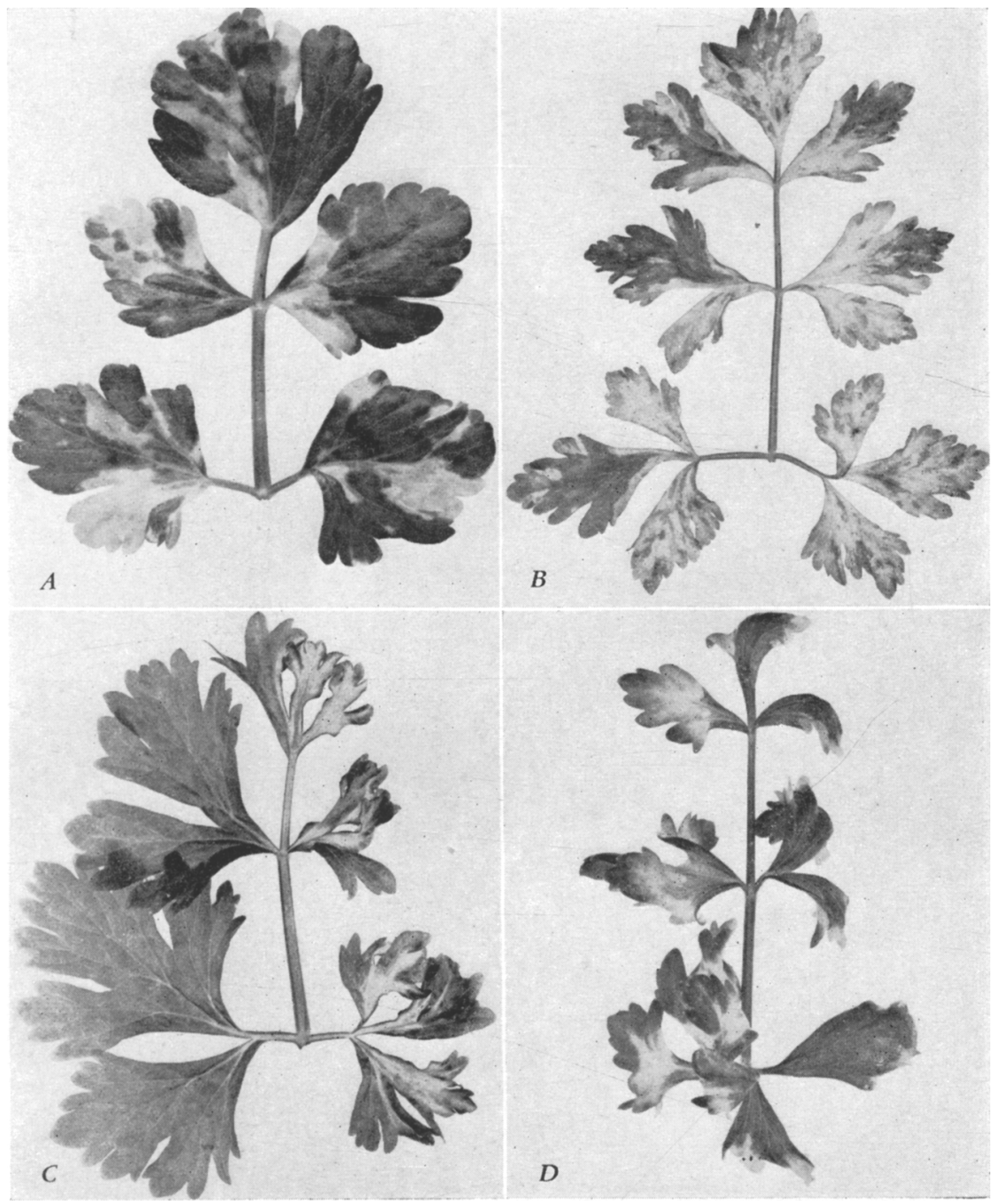

Plate 3. Symptoms of western cucumber mosaic on experimentally infected Golden Selfblanching celery (Apium graveolens var. dulce): $A$, green blister-like elevations; $B$, green islands in yellow areas resembling similar symptoms of celery calico; $C$, chlorotic and twisted leaflets on one side of the rachis, and green, apparently normal leaflets on the opposite side; $D$, twisted and chlorotic leaflets on both sides of the rachis. 


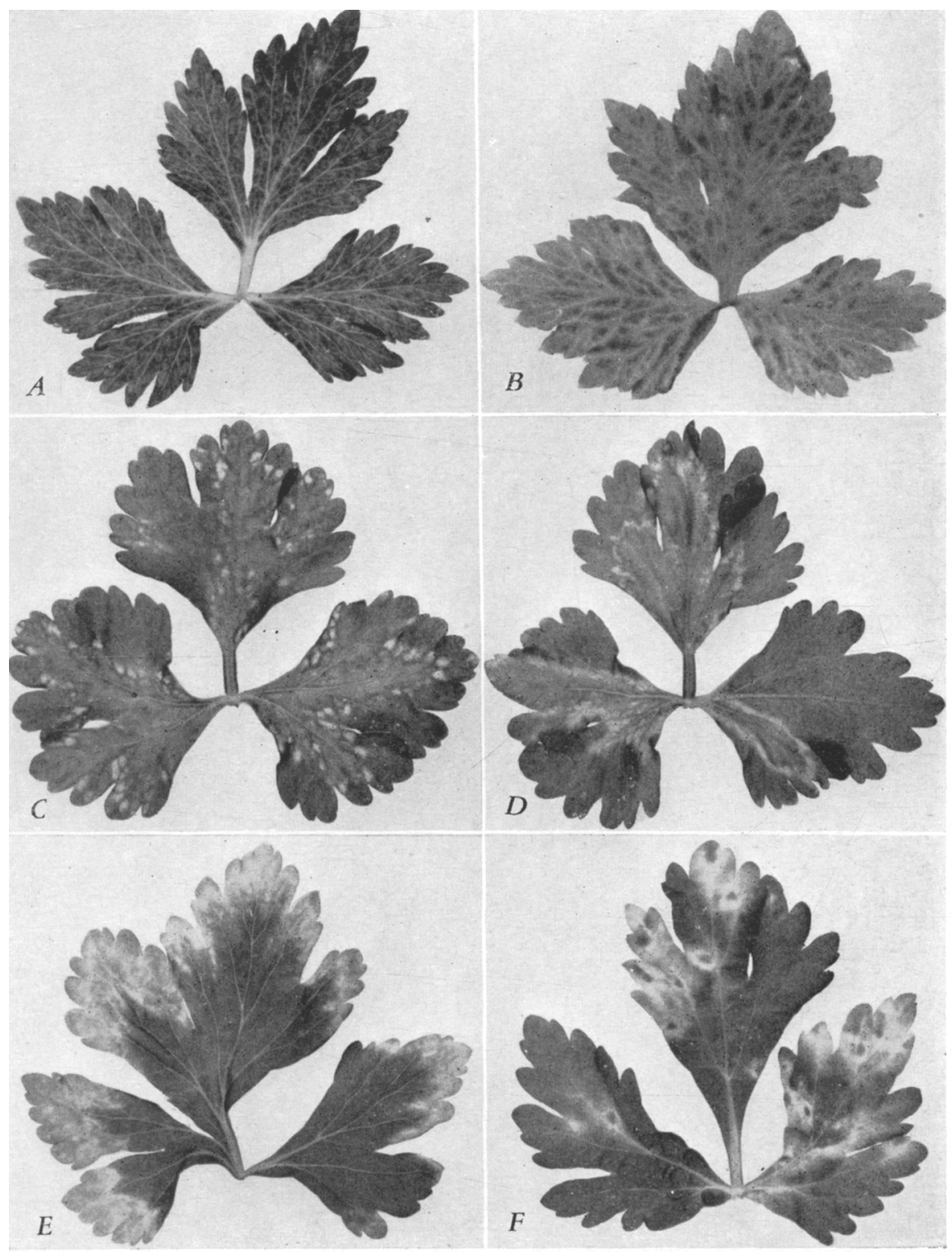

Plate 4. Symptoms of common cucumber mosaic on Golden Self-blanching celery (Apium graveolens var. dulce): $A$, cleared veins and veinlets on youngest leaf; $B$, green areas slightly elevated surrounded by cleared veins; $C$, interveinal, small, circular chlorotic areas on youngest leaf; $D$, yellow bands formed by the fusion of chlorotic areas; $E$, yellow margin on old leaf; $F$, green islands in yellow areas on old leaf, resembling a similar symptom of celery calico. 


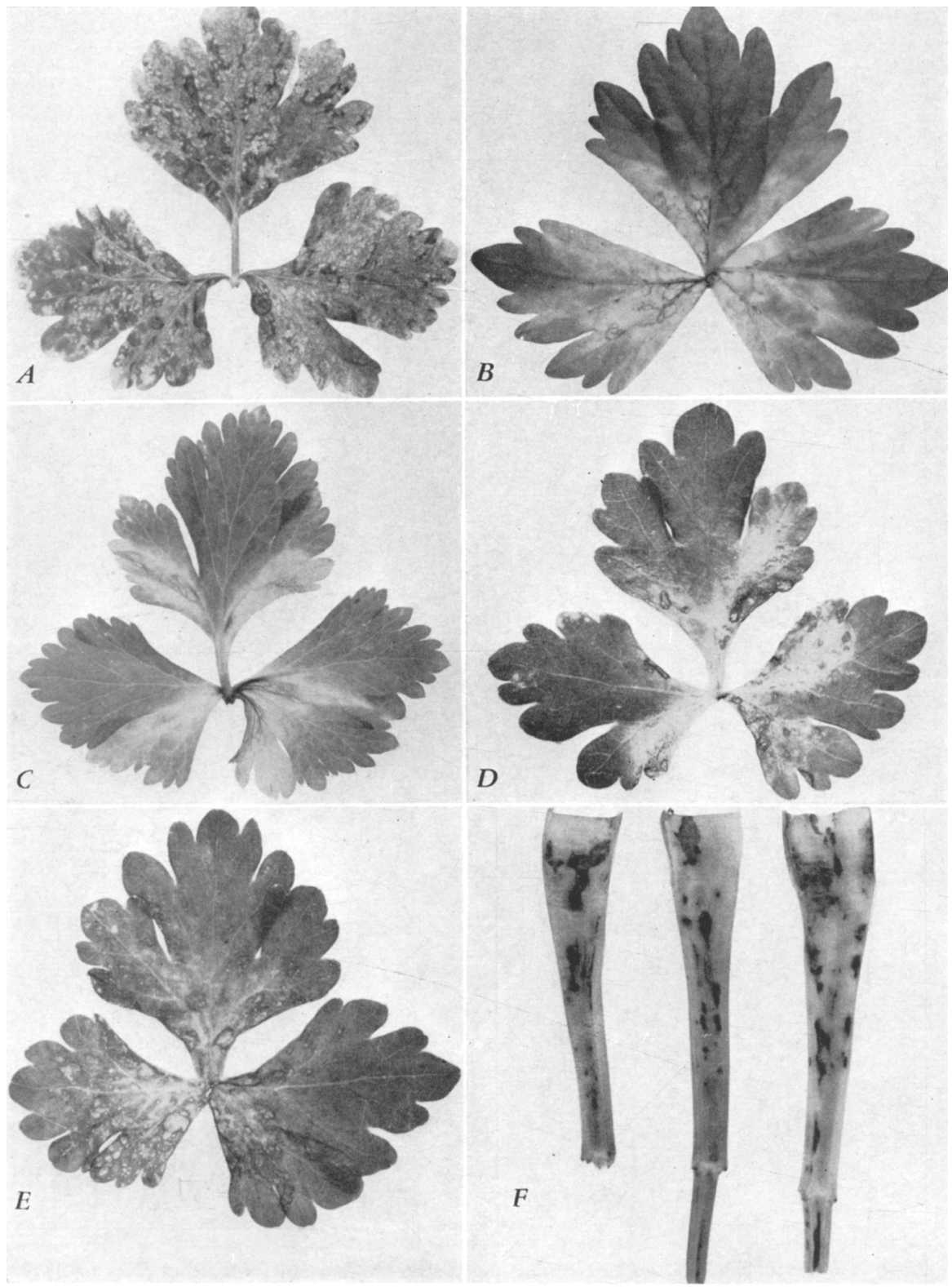

Plate 5. Symptoms of common cucumber mosaic on Golden Self-blanching celery (Apium graveolens var. dulce): $A$, numerous chlorotic areas which often fuse on old leaf; $B, C$, necrosis of veins; $D$, rust-colored, necrotic areas which gradually increase in number at $E$ on the leaflets; $F$, lesions on petioles. 


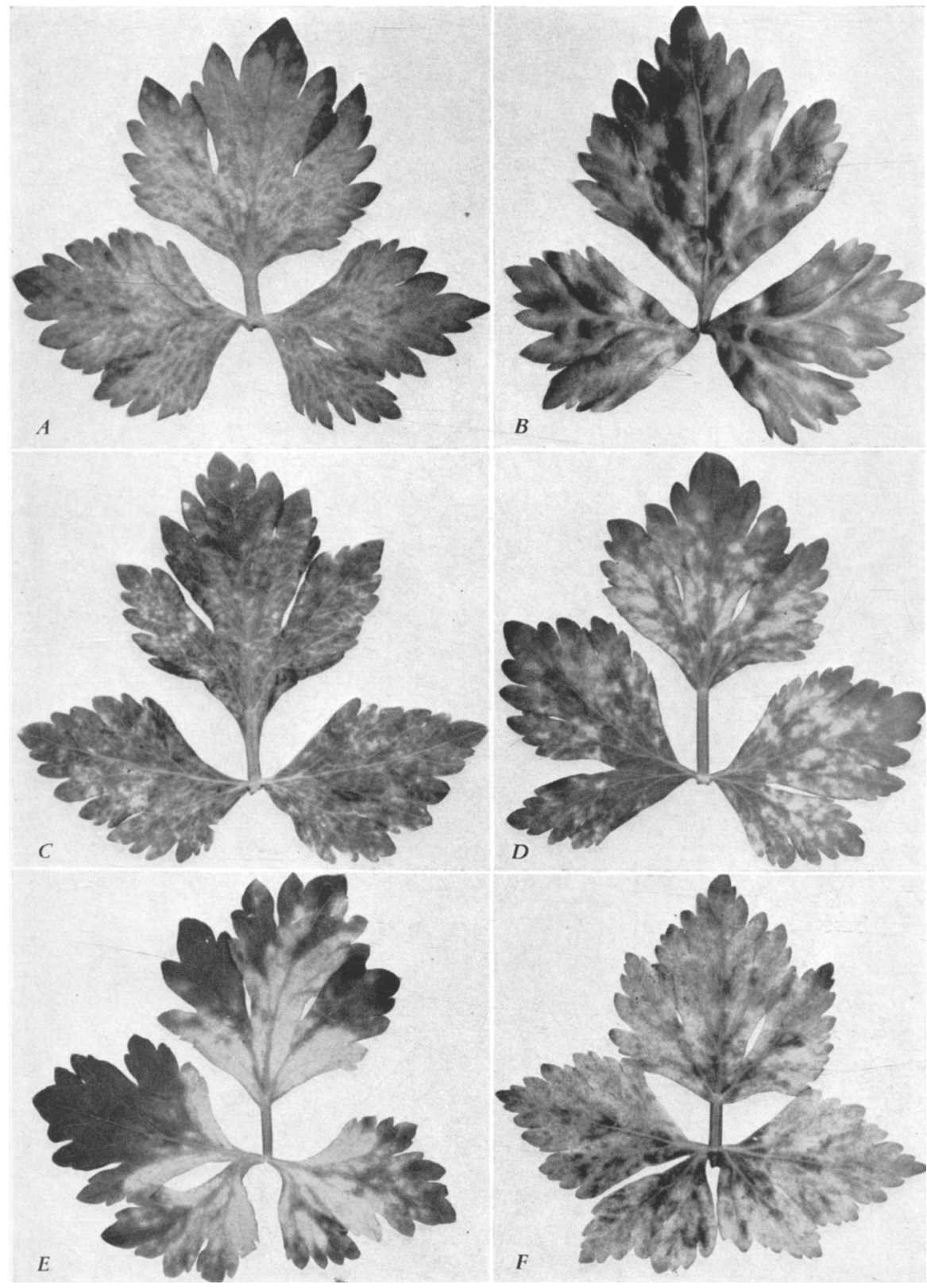

Plate 6. Symptoms of tobacco ringspot on leaflets of experimentally infected Golden Selfblanching celery (Apium graveolens var. dulce): $A$, elearing of veins and veinlets, interveinal green and chlorotic areas on youngest leaflets; $B$, interveinal circular green areas elevated on upper surface of youngest leaflets; $C$, numerous small circular chlorotic areas on intermediate leaflets; $D$, fusion of chlorotic areas; $E$, orange discoloration of intermediate leaflets; $\boldsymbol{F}$, chlorosis spreading over intermediate leaflets. 

The journal Hilgardia is published at irregular intervals, in volumes of about 600 pages. The number of issues per volume varies.

Subscriptions are not sold. The periodical is sent as published only to libraries, or to institutions in foreign countries having publications to offer in exchange.

You may obtain a single copy of any issue free, as long as the supply lasts; please request by volume and issue number from:

\section{Publications Office \\ College of Agriculture \\ Berkeley 4, California}

The limit to nonresidents of California is 10 separate issues on a single order. A list of the issues still available will be sent on request. 